\title{
BRIEFING: THE APPEAL OF THIRD TERMISM AND MILITARISM IN BURUNDI
}

'Any leader who cannot imagine life without leading or the country surviving without him is on an expensive ego trip on the backs of his or her own peoples' (Tajudeen Abdul-Raheem 2007, npn).

The recent political crisis that has engulfed Burundi since the announcement on 25 April 2015 by Burundi’s ruling party Conseil National Pour la Défense de la Démocratie - Forces pour la Défense de la Démocratie (CNDD/FDD) that its leader and President Pierre Nkurunziza was endorsed as its candidate for the planned June 2015 Presidential elections for an unconstitutional third term was not unexpected by those who follow Burundi’s politics. Nkurunziza never concealed his desire to run and those opposed to his candidacy have never hidden their intention to contest it. Burundians took to the streets of Bujumbura, and such demonstrations have led to the death of over 80 people, mainly protestors killed by the security forces (Amnesty International 2015). Post-election violence persists with tit-for-tat killing of truling party members and opposition leaders and supporters. In addition, over 170,000 people have fled as refugees to neighbouring countries to escape the violence and insecurity (UNHCR 2015). The protests were foreseeable, perhaps even inevitable, occurring against a backdrop of sustained militarism, political and economic repression, intimidation, marginalisation and exclusion, and widespread fear.

Most observers misjudged the extent to which Nkurunziza was able to defy his citizens and most of international public opinion. He survived an attempted coup on 13 May 2015, whilst attending an East African Community (EAC) meeting on the crisis in Burundi in Dar es 
Salaam, Tanzania, held elections from which he emerged victorious, and has continued to repress violently those opposed to his third term - within and outside of his party, taking Burundi to the precipice of civil war. The assassination of General Adolphe Nshmirimana the head of the National Intelligence Service (SNR) on the 2 August 2015 signalled an escalation of the conflict and was a major blow to the regime, since the general was central to the ability of the state to resist the coup and ran the notorious SNR which, reportedly, has been involved in in some of the arbitrary arrests and torture (Amnesty International 2015). Nkurunziza's ability to enforce his third term bid, despite widespread opposition, within and outside his party, is dependent on several factors - both internal and external: from the complexity of the political forces within Burundi, the role of the EAC and the strength of the military - a development attributable to the presence of Burundian peace-keepers in United Nations and regional peace-keeping missions, notably the African Union Mission in Somalia (AMISOM).

It was widely expected that the President would seek a third term despite mounting opposition. Nkurunziza has consistently argued that the term limits contained in the 2000 Arusha Peace and Reconciliation Agreement and the Constitution do not apply to him because he was not elected by popular vote in 2005. Article 7.3 of the Agreement clearly states that no President can serve more than two terms. The Constitution, which followed the principles laid down in the Agreement, states that the President should be elected by universal suffrage and this is renewable once. In 2005, Nkurunziza was first elected through an indirect vote within the National Assembly and Senate, after his party CNDD/FDD won the largest share of the vote in the first democratic elections after the transitional government established by the Agreement. Nkurunziza argued this means that he is able to stand for a third term - a position that was controversially endorsed by the Constitutional Court on 5 
May 2015 (Al Jazeera 2015; Kambanda 2015). Nkurunziza and his supporters have been trying to change the Constitution since 2011 and failed in 2014 by a narrow margin in a vote in the National Assembly. The validity of the Constitutional Court's decision was questioned when, prior to the ruling, the Court's vice-president Sylvere Nimpagaritse fled the country, claiming lack of impartiality in Court judgements.

Arguably, Nkurunziza used the period from April to July to resolve in his favour the longstanding divisions within his own party that surfaced soon after CNDD/FDD gained power in 2005 and led, in 2007, to the imprisonment of Hussein Radjabu, the then chairman of the party on charges of treason. Radjabu's allies broke away from CNDD/FDD and formed a new party which joined an alliance with smaller opposition parties to fight the 2010 elections. Radjabu escaped from prison in March 2015 after serving eight years of a 13 year sentence, and, reportedly, has fled the country.

Nkurunziza fought the 2010 election, almost unchallenged, as the main opposition candidates boycotted the process after evidence of intimidation and irregularities emerged. As now, in 2010, the state intensified its authoritarian practices in the months leading up to the elections. After winning the 2010 Presidential elections, which just one opponent contesting, Nkurunziza went on to consolidate the position of his wing of the party. Then, the international community expressed concerns but quickly shifted to business as usual after the elections, with the assurance that Nkurunziza had won a landslide victory in rural areas, which implied that it was only the urban elite, especially in Bujumbura, and those in the diaspora, who were protesting. 
In the weeks leading up to the declaration of his 2015 candidacy, the President went on to crush opposition to his candidacy within his own party. High profile party members who signed a petition opposing his intention to run for a third term had their security details removed. Nkurunziza dismissed his spokesperson, Leonidas Hatungimana, and attempted to oust the President of the National Assembly, Pie Ntavyohanyuma, both of whom warned against him standing again. In a further show of strength and intent the CNDD-FDD responded to opposition protests by organising a huge pro-regime rally on the 11 April 2015. According to the party, over 50,000 people congregated in central Bujumbura in support of Nkurunziza's third term, with supporters being bussed in from around the country.

Rumours abound in Burundi about the 13 May 2015 attempted coup; whether the government had prior knowledge, and who were the principal backers? While it is still difficult to obtain verifiable information from Burundi, three things are clear: firstly, Nkurunziza's forces had sufficient military intelligence and weaponry to foil the coup, and, secondly, it allowed Nkurunziza an opportunity to purge opposition in the military; and thirdly, Nkurunziza's return to Bujumbura a few days later, via his home town, could not have happened without the support of Tanzania. Three of the coup leaders, General Cyrille Ndayirukiye and police commissioners Zenon Ndabaneze and Hermenegilde Nimenya, were arrested and charged with 'attempting to overthrow the state'. The principal leader Godefroid Niyombare, a general and former Chief of intelligence, evaded capture. The state's attempt to root out opposition more forcefully, meant that many other critics of Nkurunziza were forced to flee, including the then deputy Vice-President of the National Assembly Gervais Rufyikiri.

Nkurunziza, despite criticism from the international community that the conditions in Burundi did not allow for free or fair election and the withdrawal of election funding by the 
European Union and Belgium, persisted with elections (Government of Belgium, 2015). Parliamentary and presidential elections were postponed briefly before their completion on 29 June and 21 July 2015 respectively. CNDD/FDD and its President, Nkurunziza, were returned for a third term in elections that the UN of the international community deemed as 'not free, credible and inclusive’ (UN 2015). The party seems to have calculated that the opposition and the international community will, eventually accept the outcome of the elections. Their experience of the 2010 elections demonstrates that the international community is unlikely to disengage fully even when an election process is marred by intimidation and violence against the opposition.

\section{Regional and International Response}

In the region, the African Union seems to have returned full circle to non-interference in the internal affairs of member states, despite the change in its 2000 Constitutive Act to condemn and reject 'unconstitutional changes of governments'. Even though the African Commission Chief Nkosazana Dlamini-Zuma said at the height of the crisis that elections may not be possible in the current situation, the AU went on to back the regime by turning over the handling of the crisis to a compromised EAC (AllAfrica.com. 2015). The EAC, after three meetings on Burundi between April and July, appointed the President of Uganda Yoweri Museveni as the chief mediator. Uganda’s impartiality can be questioned, since it has worked closely with the Burundi regime as the two main contributors to AMISOM. Furthermore, Museveni's extended tenure as President of Uganda does not provide a role model for democracy.

Why are the African Union and western governments playing soft diplomacy with Burundi? The potential for civil war in Burundi to further destabilize the region and de-rail plans for 
regional economic integration are great. Nkurunziza’s commitment to regional economic integration with Tanzania may be of significance. Part of the hesitancy also is due to the role Burundi’s military is playing in regional and international peace-keeping. Burundi's army has been integrated into peace-keeping missions in Africa, especially in AMISOM (African Union Mission to Somalia) - where it has deployed over 5432 troops, as well as a small number of police. Burundi has the second largest contingent after Uganda, which means replacing them would be difficult in the short-term and could lead to military setbacks against Al Shabaab.

International peace-keeping has been used by the Burundi state as an opportunity to strengthen its internal military capacity. Its security personnel are better trained and armed than they were before and during the war. As part of the Disarmament Demobilization and Reintegration (DDR) programme of the post-conflict security sector reform, Burundi’s military and police were supported with new weaponry and training to equip it for peacekeeping - the entire Burundi National Defence Force was trained by the US military, and private military contractors, (Northrop Grumman) under the US government’s Africa Contingency Operations Training and Assistance (ACOTA) programme (Dickinson 2011). Furthermore, Burundi obtained drones from the USA as part of a military aid package, which according to the BBC, includes 'body armour, night-vision gear, communications and surveillance systems', for 'counter-terrorism' activities' to support Burundi’s AMISOM role (BBC 2011). Further support and training have been provided to the Burundi police by Belgium and Canada as part of the Security Sector Reform programme. In 2012, SIPRI estimated that Burundi had the highest military expenditure (2.39\% of Gross Domestic Product) in the East African Community (The East African 2014). 
The international community is divided on how to respond to the political crisis. The most principled stance seems to be taken by the European Union, including Belgium, the Netherlands, and President Obama, during his visit to Africa, where he singled out Burundi for special criticism of leaders who fail to respect term limits (Obama 2015). The United Kingdom and France have been particularly quiet. An explanation for the UK stance could lie with the Conservative party, who has sought to build close relations with Burundi through special summer excursions for members of parliament to visit and participate in voluntary work. More importantly, the contract by a British company Somaoil (Manson and Burgis 2015) to explore and extract oil off the Somali coast means that Britain's interest in a stable Somali may overrule its moral responsibility to the Burundi people. Russia and China have declared support for Mr Nkurunziza, blocking any action against Burundi by the Security Council. France, the other key player in the region, has been relatively silent. Peace-making in Somalia and economic opportunities seem to outweigh peace-building in Burundi.

\section{Civil Society Protestors}

It is commonly noted that there are two civil societies in Burundi, a small but vocal civil society largely based in Bujumbura, and another based in the provinces. Many of the organisations that belong to the first group focus on combatting governance and human rights violations and see themselves as a watchdog that is responsible for holding the government to account. Civil society opposition to the current Government has visibly increased in the months prior to the elections. In January, protests followed the arrest of Bob Rugarika, the head of the largest independent radio station, Radio Publique Africaine. Upon his release, thousands took to the street in a huge, spontaneous protest. January also saw the establishment of the civil society campaign against the third mandate, where organisations came together under the banner 'Halte au troisième mandat!' (Stop the third term!) to 
coordinate civil society opposition to Nkurunziza’s candidacy. The coalition, led by FORSC (Forum pour le Renforcement de la Société Civile), FOCODE (Forum pour la Conscience et le Développement), APRODH (Association Burundaise pour la Protection des Droits Humains et des Personnes Détenues), and ACAT Burundi (L'Action des Chrétiens pour l'Abolition de la Torture au Burundi), has issued numerous statements against the third term. In April, they called on Bujumbura motorists to sound their horns in unison against the third mandate. Burundians responded en masse, creating a noise that could be heard from the hills surrounding the city. The coalition called for Burundians to take to the streets in their thousands following the announcement that Nkurunziza would stand again, and have played a key role in coordinating protests in the run up to the elections.

The current protests are taking place against a backdrop of rising tensions between civil society and the Government. Generally speaking democratisation has done little to support broad-based participation in formal political institutions and processes. At the national level few formal spaces for civil society engagement exist. For example, although they were involved in consultations around the newly-formed Truth and Reconciliation Commission to investigate past crimes, civil society has been excluded from the make-up of the Commission itself, despite calls by the public for it to be comprised of individuals from a mix of backgrounds. There are often more opportunities for the inclusion of ordinary citizens in decision-making processes at a local level, yet the vast majority of decisions continue to be made behind closed doors. Civil society groups have sought to increase levels of participation through supporting initiatives that promote local governance and accountability, such as participatory governance committees and peace clubs. Yet, the spaces for participation they create are often informal and limited. 
Feelings of political exclusion have been reinforced by restrictions placed on protest and dissent. Over the past two years the Government has introduced laws designed to increase control over independent media and public gatherings. The Law on Demonstrations and Public Meetings passed in December 2013, allows the authorities to prevent public assemblies and effectively bans spontaneous protests and those not approved by the authorities. Changes in legislation have forced demonstrators to find increasingly creative ways to express discontent. One way that civil society actors have sought to do this is by encouraging Burundians to wear green every Tuesday in solidarity with imprisoned activists and the causes they championed. The Mardi Vert movement, as it is known, has successfully enabled ordinary Burundians to engage in protest without violating the law. But many of those who openly criticise the Government have been intimidated and harassed. High profile civil society activists reported receiving phone calls in the middle of the night and seeing strange people hanging around outside their homes in recent months. Others received serious threats to themselves and their families. The most glaring has been the shooting of the widely-respected human rights activist Pierre-Claver Mbonimpa on 3 August 2015, in almost a reprisal after the assassination of General Adolphe Nshimirimana the day before; the failure to kill mbonimpa may have accounted for the assassination of form army chiefColonel Jean Bikomagu Two key figures belonging to the parties opposed to the third term have been assassinated, Zedi Feruzi (23 May 2015) and Patrice Gahungu (7 September 2015) of the Union for Peace and Development- Zigamibanga) - a party established by former members of CNDD/FDD. While repressing opposition is nothing new in Burundi, recent efforts have further exacerbated existing pressures between the Government and its critics.

\section{Youth Militias}


A characteristic of the Burundi politics is the establishment and arming of youth militias by political parties. The Imbonerakure (those who see far), the youth wing of CNDD/FDD, has figured prominently in the discussion about violence against peaceful protestors. Human Rights Watch’s Africa Director is reported to have said, 'the Imbonerakure have no legal right to arrest anyone, yet they have been stopping people arbitrarily, beating them, And handing them over to the intelligence services, who have tortured some of them' (HRW 2015, 2). Burundians continue to have real concerns about the manipulation of economically excluded young people by political actors, including the ruling party and political opposition. They are worried that young people who lack the economic and social stability that employment brings are being easily manipulated by political parties seeking to rally support and target opponents. With high rates of youth unemployment (estimated 80 per cent) and over 55 per cent of the population under 17 years of age, since the 1990s the Burundi's youth have been vulnerable to manipulation by political parties. In May 2014, a high profile human rights defender Pierre Claver Mbonimpa was arrested for leaking reports that showed the Imbonerakure was receiving military training across the border in the Democratic Republic of Congo. Over the past year, reports of small-scale attacks on civilians and opposition members by the youth militia have increased. Many of refugees who have crossed the border into neighbouring Rwanda and Tanzania have fled because they fear persecution by the Imbonerakure, who are reportedly patrolling neighbourhoods with clubs spiked with nails and painting red marks on the houses of those they intend to target.

\section{Ethnicity in the Current Crisis}

Although the recent violence appears to be political in nature, we cannot dismiss ethnicity entirely from the analysis. There are growing fears in Burundi that ethnicity will emerge as a major fault line as the political crisis progresses. Even through the demonstrators have been 
both Hutus and Tutsis, political entrepreneurs have been seeking to divide the population along ethnic lines. The ethnic (60/40 - Hutu /Tutsi respectively) and gender (30 per cent) quotas that were agreed as part of the power-sharing arrangements at Arusha were respected by all parties, until recently when the law was changed to overturn the gender quota among the senior ministers in Parliament. Parts of the former Tutsi elite, while accepting the ethnic split in government are increasingly alarmed by their marginalization from power by the current regime, especially since, for historical reasons, they constitute the bulk of the educated people in Burundi. Some Hutus, on the other hand, despite their majority in the legislative bodies, remain suspicious of Tutsis within the military and political elite, especially the presence of former presidents in the Senate.

In the late 2000s, observers of Burundi’s politics assumed that with the institutionalization and acceptance of ethnic quotas, one of the main fault lines in the society had disappeared. Yet some Burundians, in having to declare their ethnicity and unable to change it, continue to see ethnicity as an underlying factor in their experience of the state. Little work has been done on how ethnicity is manifested in the state, but alarms have been raised about the protests and killings that began in April 2015, in the Tutsi-dominated neighbourhoods of Bujumbura - Ngagara, Cibitoke, Musaga, Nyakabiga and Mutakura - and that this might be conceived by unscrupulous politicians as an ethnicized opposition. Narratives from people in Burundi about their experiences of violence indicate that ethnicity is being used as a discriminatory tool on the ground by the Imbonerakure and the SNR (HRW 2015).

While all political parties are expected to have allowed for both Hutu and Tutsi members, the participation in the presidential elections by the main Hutu opposition leader Agathon Rwasa (National Front for Liberation), and his taking up of the post of First Deputy Speaker of the 
National Assembly may expose Tutsi leaders in the opposition and strengthen claims of an ethnic dimensions to the current protests. One could draw some reassurance that in 2010 ethnicity was not a factor in the elections, but the dynamics may be different depending on how quickly the situation is resolved. In pre-war Burundi regimes, the Tutsi-dominated military was instrumental to the repression and the persistence of ethnic conflict. With the integration of Hutu rebel groups into the rank-and file and gradually into the senior ranks, the balance of power is not clear, although a Hutu was head of the military.

\section{Continued Economic Impoverishment}

Economic marginalisation has also contributed to rising tensions. Increasing cost of living and a crippling petrol crisis have made life more and more difficult for ordinary Burundians. Inflation is still high and has mainly been over 10 per cent since the early 2000s. The economy is in the midst of the second period of the World Bank sponsored Poverty Reduction Strategy (PRSPII), which, with its neo-liberal economic prescriptions of liberalization and privatization, has not improved the conditions of life for the majority. In March, the civil society coalition, Le Campagne Contre La Vie Cher (The campaign against the rising cost of living), brought the capital to a standstill, encouraging Burundians to stay at home in protest at the Government's failure to respond to rising living costs. While the leaders of the protests are themselves often from relatively affluent or middle class backgrounds, they have tapped into the concerns of Burundians who feel that the Government is doing little to make life better for them and their families. But it's not only civil society and protest leaders that are exploiting the frustrations and discontent generated by political and economic marginalisation. 
A major source of conflict that is feeding into the wider political protests is that over land. With its high population density 400 people per square kilometre competition for land has long been severe but has intensified with the return of over a million refugees in the post-war period - many of whom have found their former lands occupied, sometimes by the state, by members of the elite, or peasant neighbours. The Arusha Accords allowed for the establishment of the National Land Commission (CNTB) in 2006, which has not led to speedier or more satisfactory resolution of land conflicts (Keenan 2015). Even though settling over 40,000 disputes, CNTB has been criticised for being subjected to political interference and discriminatory practices. Tutsis, who may have acquired property during the Tutsi-dominated regimes of the 1980s and 1990s, see themselves as being more vulnerable under a Hutu-dominated government. Protests over land resolutions have not just been confined to the capital, but are more widespread in southern regions such as Makamba, where land conflicts and economic desperation are acute.

\section{Enduring Militarism: Political Exclusion and Violence}

With regards to the democratic politics, it is debateable the extent to which rebel leaders can, after gaining power through democratic elections, adhere to the principles of democracy. In 2008, Daley wrote that Burundi exhibits the characteristics of a genocidal state; that its histories of ethnic differentiation and the dominance of the state and the security services by particular ethnicities serve to reproduce overt and direct violence against its citizens as normative state practice. The main Burundian rebel groups were not signatories to the Arusha Accords and, despite signing peace agreements with the interim governments, it was clear that their adherence to the principles of Arusha was partly under duress from the international community and their desperate need for external aid. While there have been signs that CNDD/FDD was not committed to Arusha, the international community wanted signs of 
success and Arusha provided a legitimate framework for the sort of neo-liberal peacebuilding that were popular.

Post the peace agreement, both the interim government and Pierre Nkurunziza's first regime were marred by political violence and continued violations of human rights and intolerance of critics. The state has imprisoned, intimidated its critics, shutdown radio stations, and, in a culture of impunity, extrajudicial killings have occurred. One example was the assassination of the anti-corruption campaigner Ernest Manirumva in 2009. Such low intensity violence has occurred in a context where the ruling party has consolidated its grip over state institutions, whether it's the Office of the Ombudsman, the National Land Commission, the reformed judiciary, and the Anti-Corruption Court - institutions that were established from Arusha or from pressure from the international community. With the power exerted by the ruling party over these supposedly independent institutions, it is not surprising that, facing violent opposition, President Nkurunziza went the Constitutional Court to legitimize his candidature for a third term.

While the situation has improved compared to the previous 1990s regime under Pierre Buyoya, power-holders in Burundi have not thought through alternative ways of governing the society. The UN remained almost impotent to these violations, for reasons of sovereignty, it responded to government calls to scale down its peace-keeping presence in the country, shifting its policies from centralized peace-building to stabilization, in which western development practitioners, humanitarian actors, and military personnel combine to take on the task of stabilizing and transforming the conflict-ridden society. Since building societies in the image of western democracies is inevitably slow, stabilization appears to be an 
unending intervention, and, as Bachmann and Gelot (2012, 137) acknowledge, 'has made the emergence of internationalized and militarized forms of administration possible’.

\section{Conclusion}

There are four key lessons to be learnt from the current crisis in Burundi. Firstly, rebel leaders have to be brought into any democratic peace negotiations. In the case of Arusha, Nyerere the facilitator took a moral stance in not recognizing those who sought change through force, and rebel leaders refused to negotiate with the then Tutsi-dominated regime. In this case, long-term indicators, in addition to free and fair elections, should have been devised to demonstrate former rebel leaders' commitment to the democratic process, even if the rhetoric of their rebellion is to restore democracy.

Secondly, the nature of security sector reform that includes the deployment of new armies into global and regional peace-keeping missions, supported by professional training by western military forces, needs to be rethought. It may appear to solve many problems at once; chief among them providing access to financial and military resources in the hope that this will prevent a return to war; it also boosts the military preparedness of a government whose commitment to peace is still unproven. President Nkurunziza appears to interpret any opposition to his regime in a militaristic sense, calling the protestors "insurgents", and the security services seem to have been unable to distinguish between peaceful protests and terrorism - bringing the rhetoric associated with the Somali conflict to the domestic space.

Thirdly, national political histories matter; new democratic practices do not arise solely from the international community, debates about the nature of the post-conflict state need to take place outside the conference all and in the wider society . President Nkurunziza has no other 
model of the state than a genocidal one. His party is probably still the most popular party in Burundi, and may have won the elections with a diminished majority. However, unable to tolerate difference within his own party or to see the party without his leadership, he is in danger of turning Burundi into an authoritarian state.

Fourthly, in post-conflict contexts, regional and international vested interests can be forces for peace, as well as for persistent violence and insecurities. Burundian lives should not be discounted for wider monetary gains, whether its regional infrastructural development or future mineral resources temporarily blocked by insecurity. Furthermore, regional interventions, to date, have not averted the potential for civil war in Burundi to further destabilize the region and de-rail plans for regional economic integration. It behoves progressive forces, both within and outside of Burundi, to make the case that another peace is not only possible, but absolutely necessary. The African Union and the United Nations should not wait for more deaths before taking a principled stance. Burundian lives should matter.

\section{References}

Abdul-Raheem, Tajudeen. 1 November 2011. 'In defence of ten theses of leadership’, Pambazuka News.org. Accessed at: http://pambazuka.net/en/category/panafrican/39172.

AllAfrica.com. 8 May 2015. 'Burundi - AU Says Environment Not Conducive for Elections, interview by Girum Chala.

Accessed at: http://allafrica.com/stories/201505081091.html. 
Al-Jazeera. 6 May 2015. 'Burundi Court backs President's candidacy amid unrest'. Accessed at: http://www.aljazeera.com/news/2015/05/burundi-court-validates-presidentterm-bid-150505095216200.html.

Amnesty International.2015.Braving Bullets: Excessive force in Policing Demonstrations in Burundi.

Accessed at: https://www.amnesty.org/en/documents/afr16/2100/2015/en/

Bachmann, Jan and Linnéa Gelot. 2012. ‘Between Protection and Stabilization? Addressing the Tensions in Contemporary Western Interventions in Africa: An Introduction’. African Security 5 (3-4): 129-141.

BBC News. 28 June 2011. 'Uganda and Burundi to get US drones to fight Islamists'. Accessed at: http://www.bbc.co.uk/news/world-africa-13946702.

Daley, Patricia.2008. Gender and Genocide in Burundi: The Search for Spaces of Peace in Central Africa. James Currey; Bloomington, Indiana: Indiana University Press; Kampala, Uganda: Fontana

Dickinson, Elizabeth. 22 December 2011. 'For tiny Burundi, big returns in sending peacekeepers to Somalia'.Christian Science Monitor.

Accessed at: http://www.csmonitor.com/World/Africa/2011/1222/For-tiny-Burundi-bigreturns-in-sending-peacekeepers-to-Somalia 
Human Rights watch (HRW). 6 August 2015. 'Burundi: Spate of Arbitrary Arrests, Torture: Intelligence Officials, Ruling Party Youth Target Suspected Opponents’.

Accessed at: https://www.hrw.org/news/2015/08/06/burundi-spate-arbitrary-arrests-torture

Kambanda, Charles K.M. 3 June 2015. Understanding Burundi’s turmoil: Is it a constitutional crisis or political and economic issues? Pambazuka News, Issue 729. Accessed at: http://pambazuka.org/en/category/features/948490

Keenan, Jillian. 27 March 2015. 'The Blood Cries Out'. Foreign Policy Accessed at: http://foreignpolicy.com/2015/03/27/the-blood-cries-out-burundi-land-conflict/ Government of Belgium. 11 May 2015. 'Le soutien aux élections burundaises et la coopération policière suspendus’. Accessed at:

http://countries.diplomatie.belgium.be/fr/burundi/newsroom/news.jsp?id=266894\&title=ni_1 $\underline{10515 \text { burundi }}$

Manson, Katrina and Tom Burgis. 8August 2015. 'Somalia corruption probe: minister asked Lord Howard for funding'. Accessed at: http://www.ft.com/cms/s/0/dedbada0-3d19-11e5bbd1-

Obama, Barack. 28 July 2015. 'Remarks by President Obama to the People of Africa'. Accessed on 10 August 2015 at https://www.whitehouse.gov/the-pressoffice/2015/07/28/remarks-president-obama-people-africa

The East African. 16 April 2014. 'Uganda, Burundi lead East Africa in Military Spending'. 
Accessed at: http://www.theeastafrican.co.ke/news/Uganda--Burundi-lead-East-Africa-inmilitary-spending.

United Nations (UN). 27 July 2015. 'UN mission finds overall environment in Burundi ‘not conducive’ to credible election process'. UN News Centre.

Accessed at: http://www.un.org/apps/news/story.asp?NewsID=51507\#.VcuprFRVhBc

UNHCR. 2015. 'Burundi Situation: Displacement of Burundians into Neighbouring

Countries (as of 20 July 2015)'. Accessed 10 August 2015 at

http://reliefweb.int/map/burundi/burundi-situation-displacement-burundians-neighbouringcountries-20-july-2015. 